\title{
DETERMINATION OF SUPERIOR PARENTS AND HYBRID COMBINATIONS FOR EARLINESS CHARACTERS FOR LINE $X$ TESTER HYBRIDS OF COTTON
}

\section{EL- AGAMY A. I. ${ }^{1}$, H. E. YASSIEN ${ }^{1}$, T. A. EL-FEKI ${ }^{2}$ AND H. A. EL- HOSEINY ${ }^{2}$}

1. Faculty of Agriculture, Al-Azhar University

2. Cotton Research Institute, ARC, Giza

(Manuscript received 26 march 2007)

\begin{abstract}
The objective of this study was to determine estimates of heterosis, general combining ability of parents and specific combining ability of hybrids needed in breeding super early cotton cultivars. Five cotton lines Pima S6, G.88, G.83, and Suvin in addition the promising hybrid $\{$ G. $84 \times(\mathrm{G} .74 \times$ G.68)\} and five tester parental (Early Pima, Giza 45, Sea Island, Dendara and Giza 90) were crossed in line $x$ tester mating system at Sakha Research Station, Agric. Res. Center in 2001. Ten parental genotypes and their $25 \mathrm{~F} 1 \mathrm{~s}$ hybrids were grown in randomized complete block design in four replication at Sakha in 2002. Significant heterosis over all crosses for position of first fruiting node and days to first flower were obtained. Line $\mathrm{x}$ tester analysis revealed significant general and specific combining ability effects for position of first fruiting node and days to first flower appearance. The ratio of GCA/SCA reflects the magnitude of dominance for position of first fruiting node and days to first flower appearance. Line parental Suvin is a good combiner for all traits except for earliness index. However the breeder cannot predict GCA of any genotype in the use performance of these parental varieties. Low narrow sense heritability estimates (below $30 \%$ ) were obtained for days to first boll, earliness index. Medium values ( $30-50 \%$ ) were obtained for position to first fruiting node and days to first flower appearance. The results showed that the parental variety Pima S6 and hybrid Pima S6 $\times$ Sea Island have higher diversity.
\end{abstract}

\section{INTRODUCTION}

Enhancement for earliness in cotton has occurred as staying period cotton was shortened from 270 days to 210 days. This improvement cannot be attributed to management practices only but aiso due to genetic improvement of cultivars. EL-Feki (1986) indicated that no significant differences for heterosis relative to mid-parent were obtained for earliness characters. However, interspecific hybrids had shown negative heterotic effects for days to first flower, days to first boll opening and positive heterotic effect for earliness index. While intraspecific hybrids had positive heterotic effect for days to first flower in ( $G$. barbadense $L$ ) and days to first boll opening and earliness index in ( $G$. hirsutum L). According to the GCA/ SCA ratio the additive genetic variance had greater magnitude for days to first flower. Gomaa and Shaheen 
(1995-a) cleared from the studies of some Egyptian cotton crosses that heterosis for earliness index was positive and significant in one cross, with respect to other crosses, the heterosis was desirable negative and highly significant for days to first flower, days to first boll opening, position of the first fruiting node and earliness index. They also observed that the additive effect was the most important in controlling the earliness trait, i.e. days to first flower, days to first boll opening, position of the first fruiting node and earliness index. Tomar and Singh (1996) studied a line $x$ tester mating set obtained by crossing 20 diverse genotypes (female) with three male adapted genotypes (male) of Asiatic cotton and indicated that non additive genetic effects were predominant in the inheritance of days to flower initiation. El-Adl et al. (2000) reported that heritability values in the broad sense were $56.4 \%, 40 \%$ and $1.70 \%$ for days to first flower, days to first boll opening and earliness index, respectively. El-Tabbakh and El-Nakhlawy (1995) investigated inter-specific crosses of G. barbadense $\times$ G. hirsutum. They observed that the general combining ability (GCA) variance was not significant for height of first fruiting node and earliness index. On the other hand SCA variance was significant for height of first fruiting node while, it was highly significant for earliness index, suggesting that non-additive genetic variance was predominant over additive genetic variance in the inheritance of these traits. Awad (2001) stated that heterosis relative to mid-parents was desirable negative and highly significant for first fruiting node, days to first flower and days to first boll opening. Moreover, heterosis over better-parent was significant for first fruiting node, while days to first flower was insignificant. Therefore this study aimed to investigate the inheritance of earliness characters and determine the superior parents and hybrids.

\section{MATERIALS AND METHODS}

The plant material used in the present study were obtained by ine $x$ tester crossing. The five cultivars used herein, as line were Pima S6, G.88, G.83, \{G.84 x (G.74 x G.68)\} and Suvin (Indian variety), it is belonging to Gossypium barbadense L. and resulted from the crossing between Sujata $x$ Vincent varieties. The tester varieties were Early Pima, Giza 45, Sea Island 12/132, Dendara and Giza 90. 25 F1,s seed and parental varieties were planted to obtain selfed seed in the season 2001.

In the next season, the seeds of $25 \mathrm{~F} 1, \mathrm{~s}$ and ten parental varieties were sown in randomized complete block design experiment with four replications at Sakha Agricultural Research Station. Each plot consisted of three rows. The rows were 4 meter long and $65 \mathrm{~cm}$ apart. Hills were spaced at $20 \mathrm{~cm}$ within rows and seedlings were thinned at two plant / hill. Conventional cultural practices were followed through 
the growing season. The measurements, were recorded on ten individual guarded plants from the middle row of each plot.

\section{The studied traits:}

1. First fruiting node.

2. Days to first flower appearance.

3. Days to first boll opening.

\section{Earliness index.}

The data for all traits were analyzed to estimate the mean variance and the standard error. Heterosis over mid-parent (F1-M.p) and useful heterosis (F1- better parent) were computed and tested for significance using the test.

$\begin{aligned} \text { Standard error for mid-parents heterosis } & =\sqrt{\frac{3 M S e}{2 r}} \\ \text { Standard error for better-parent heterosis } & =\sqrt{\frac{2 M S e}{r}}\end{aligned}$

The general combining ability variance of parent and specific combining ability variance of hybrids were estimated via line $x$ tester variance analysis according to Singh and Chaudhary (1977). The Microsoft excel computer programme was used to analize the data of general (GCA) and specific (SCA) effects using a 2 way table with the following formula:

$$
\begin{gathered}
\text { For lines } g i=\frac{X i . .}{\operatorname{tr}}-\frac{X \ldots}{L t r} \\
\text { For testers gi }=\frac{X . j .}{L r}-\frac{X \ldots}{L t r} \\
\text { Sij }=\frac{X i j .}{r}-\frac{X i . .}{\operatorname{tr}}-\frac{X . j .}{L r}+\frac{X \ldots}{L t r}
\end{gathered}
$$

Where

$\mathrm{Sij}=$ specific combining ability effects for cross between line and tester.

$X_{i j} .=$ Total value of cross between lines and testers over replications,

$\mathrm{Xi} . ., \mathrm{X} . \mathrm{j} ., \mathrm{X}$..., $\mathrm{L}, \mathrm{t}$ and $\mathrm{r}$ symbols are as mentioned before.

Cluster analysis was performed on genotypes ( $r$ ) matrix using measure of square Euclidean distance and genotypes were clustered. The genotype groups were sequently clustered based on similarity of genotypes and the distance between clusters was measured using the original quantitative characters after calculating the standard units.

\section{RESULTS AND DISCUSSION}

\section{Analysis of variance.}

The analysis of variance of five lines, five testers and their 25 top crosses for earliness are presented in Table (1). Mean squares of genotypes (parent and their 
F1's) were highly significant which indicating the genotype variability and genetic materials were valid to proceed further analysis further analysis. Mean squares for parent vs. Crosses, as indication of the average heterosis over all crosses were significant for position of first fruiting node and days to first flower, it was insignificant for days to first boll opening and earliness index. Same results for days to first flower was obtained by Abo-El-Yazied (1999) and Awad (2001). The variance of crosses were partitioned into the main effects where lines and testers which are equivalent to general combining ability (GCA) Its is equal to half additive genetic variance and line $x$ testers interaction as indication of specific combining ability SCA (Hallawer and Miranda 1988).

Table 1. Mean squares of Earliness measurements in Top-Crosses mating design

\begin{tabular}{|l|c|l|l|l|l|}
\hline \multicolumn{1}{|c|}{ Sourse } & d.f & $\begin{array}{c}\text { First } \\
\text { fruiting } \\
\text { node }\end{array}$ & $\begin{array}{c}\text { Days to first } \\
\text { flower }\end{array}$ & $\begin{array}{c}\text { Days to first } \\
\text { boll opening }\end{array}$ & \multicolumn{1}{|c|}{$\begin{array}{c}\text { Earliness } \\
\text { index }\end{array}$} \\
\hline Replicate (r) & 3 & 0.041 & 0.15 & 4.60 & 72.10 \\
Genotypes (G) & 34 & $1.971^{* *}$ & $70.06^{* *}$ & $16.92^{* *}$ & $265.25^{* *}$ \\
Parents (p) & 9 & $2.865^{* *}$ & $87.95^{* *}$ & $22.23^{* *}$ & $445.53^{* *}$ \\
Crosses & 24 & $1.695^{* *}$ & $61.80^{* *}$ & $15.61^{* *}$ & $201.81^{*}$ \\
Par. vs. Cross & 1 & $0.552^{* *}$ & $107.48^{* *}$ & 0.43 & 165.46 \\
Lines (L) & 4 & $8.258^{* *}$ & $171.022^{* *}$ & $32.43^{* *}$ & $560.70^{*}$ \\
Tester (T) & 4 & 0.308 & $139.127^{* *}$ & $34.76^{* *}$ & 146.65 \\
LXT & 16 & $0.402^{* *}$ & $15.164^{* *}$ & $6.62^{*}$ & 125.88 \\
Error & 102 & 0.060 & 0.384 & 3.28 & 113.29 \\
\hline G.C.A & & $0.024^{* *}$ & $0.874^{* *}$ & $0.169^{* *}$ & 1.424 \\
S.C.A & & $0.085^{* *}$ & $3.695^{* *}$ & $0.835^{* *}$ & 3.148 \\
G.C.A/ S.C.A & & 0.282 & 0.237 & 0.202 & 0.452 \\
Additive & & $0.049^{*}$ & $1.749^{*}$ & $0.337^{*}$ & 2.847 \\
Dominance & & $0.085^{*}$ & $3.695^{*}$ & $0.835^{*}$ & 3.148 \\
Error & & 0.015 & 0.096 & 0.82 & 28.32 \\
\hline
\end{tabular}

*,** Significant at $0.05 \%$ and 0.01 respectively 
Table 2. General combining ability (GCA) of lines and testers for earliness characters

\begin{tabular}{|c|c|c|c|c|c|c|c|c|}
\hline & \multicolumn{2}{|c|}{ First fruiting node } & \multicolumn{2}{|c|}{$\begin{array}{c}\text { Days to first } \\
\text { flower }\end{array}$} & \multicolumn{2}{|c|}{$\begin{array}{l}\text { Days to first boll } \\
\text { opening }\end{array}$} & \multicolumn{2}{|c|}{ Earliness index } \\
\hline & GCA & Mean & GCA & Mean & GCA & Mean & GCA & Mean \\
\hline Pima $\mathrm{S}_{6}$ & $\begin{array}{l}- \\
0.521 * *\end{array}$ & 5.65 & $3.588 *$ & 82.15 & 0.437 & 132.98 & -1.644 & 48.15 \\
\hline Giza 88 & $0.619^{\circ} \cdot$ & 6.13 & $3.892 * \bullet$ & 78.45 & 0.442 & 134.28 & $6.836^{* *}$ & 71.75 \\
\hline Giza 83 & $0.779 \cdot \bullet$ & 6.10 & $1.892^{*}$ & 73.88 & $\begin{array}{l}1.262^{*} \\
*\end{array}$ & 130.38 & -1.518 & 59.84 \\
\hline G. $84 \times(G 74 \times G .68)$ & $-0.49 \cdot \bullet$ & 6.20 & $0.78 \wedge \cdots$ & 72.83 & -0.018 & 128.65 & 2.717 & 78.08 \\
\hline Suvin & $0.386 *$. & 5.83 & $\begin{array}{l}- \\
1.408^{* *}\end{array}$ & 69.58 & $\begin{array}{l}2.123^{*} \\
*\end{array}$ & 130.55 & $7.282^{* *}$ & 55.53 \\
\hline Early Pima & 0.019 & 5.43 & $3.857^{* *}$ & 71.20 & $\begin{array}{l}1.732^{*} \\
*\end{array}$ & 126.85 & -4.327 & 69.53 \\
\hline Sea Island & $0.184^{\bullet *}$ & 7.45 & 0.177 & 82.18 & $0.972^{*}$ & 129.35 & 0.390 & 56.55 \\
\hline Giza 45 & $\begin{array}{l}- \\
0.146 * .\end{array}$ & 8.00 & $\begin{array}{l}- \\
0.568^{* *}\end{array}$ & 80.38 & $\begin{array}{l}1.343^{*} \\
*\end{array}$ & 132.98 & -0.543 & 57.15 \\
\hline Dendara & -0.076 & 5.60 & 0.082 & 73.93 & $1.053^{*}$ & 128.75 & 1.998 & 68.01 \\
\hline Giza 90 & 0.019 & 5.73 & $3.548^{* *}$ & 72.18 & -0.308 & 128.90 & 2.483 & 80.02 \\
\hline L.S.D (0.05) & 0.109 & 0.345 & 0.274 & 0.867 & 0.806 & 2.548 & 4.736 & 14.97 \\
\hline$(0.01)$ & 0.144 & 0.457 & 0.364 & 1.150 & 1.068 & 3.378 & 6.278 & 19.85 \\
\hline Correlation. & 0.0 & & -0.1 & & & & -0.0 & \\
\hline
\end{tabular}

*, ** Significant at $0.05 \%$ and $0.01 \%$

The data in (Table 1) revealed that both GCA and SCA variances were significant for position of first fruiting node, day to first flower appearance and days to first boll opening. These results reflect the importance both GCA and SCA variances in the inheritance of these traits. The results of GCA/SCA ratio indicates that the specific combining ability were of major importance and constitute a more effective portion of genetic variance. Similar results were obtained by El-Tabbakh and Naklawy (1995) and Tomar and Singh (1996) but were disagreement with results obtained by El- Feki et al 
(1995), and Gomaa and Shaheen (1995) they found that SCA variance for earliness index was insignificant.

\section{Performance of the parents and general combining ability effects}

\section{4. a- The mean of performance}

The mean performance of the ten tested parental varieties, the mean values of parents showed differences with range of $5.03-8.00,65.45-82.18,126.8-134.3$ and $48.15-80.02$ for first fruiting node, days to first flower, days to first opening boll and earliness index respectively. (Table 2)

Regarding first fruiting node the results indicated that the parental varieties Early Pima, Giza 90, Dendara and Pima S6 did not differ significantly and exhibited Earlier mean performance for first fruiting node and the parental varieties Suvin, [G.84x (G.74 x G.68)], Giza 83 and Giza 88 did not differ significantly while the parental varieties Giza 45 and Sea Island exhibited late mean performance and the two varieties differ significantly.

Concerning days to first flower the results showed that the parental varieties Suvin and Early Pima were earlier than the other parental varieties (Table 2). The parents Sea island and Pima S6 were the latest varieties and did not differ significantly.

General combining ability effects for each of the lines and tester parents are presented in (Table 2). The data lines Pima $S_{6},[G .84 \times(G .74 \times G .68)]$ and Suvin expressed higher negative effects for position of first fruiting node and early flowering for day to first flower. Suvin female parent exhibited also GCA effect toward earliness boll opening (negative effect). Also it exhibited positive GCA effect for earliness index. These results indicated that Suvin was good combiner for earliness traits understudy. Tester Dendra was good combiner for all traits except earliness index.

The correlation coefficient of parental mean performance (lines and tester) with their respective GCA effects for earliness characters are presented in (Table 2). The correlation coefficient values were not significant for all earliness characters. It means that the breeder can not predict GCA of any genotype from mean the performance of that genotypes for any trait and can not use these varieties for developing early genotype. This conclusion disagreed with those obtained by Hassoub (1991). 


\section{Heterosis and Specific combining ability effects}

With respect to first fruiting node the results in (Table 3 ) indicated that the cross (Suvin $x$ Early Pima) was earlier than all crosses and was followed with the two hybrids (Giza $83 \times$ Early Pima) and (Suvin $\times$ Dendara) which these crosses did not differ significantly. They were followed by ([G.84 x (G.74 x G.68)] $\times$ Early Pima) was followed by crosses (Suvin $\times$ Giza 90 ) and (Suvin $\times$ Giza 45 ).

For days to first flower the results in Table (3) showed that the cross (Pima S6 $x$ Early Pima) was latest cross followed by the crosses (Pima S6 x Giza 45), (Giza $88 \times$ Giza 45), (Giza $83 \times$ sea Island), (\{G.84 (G.74 x G.68) $\} \times$ Giza 45) and (\{G.84 (G.74 x G.68)\} $\times$ Sea Island), respectively which did not differ significantly. This result was in harmony with that obtained previously, the cross of early $x$ early produce early crosses while early $x$ late produce late crosses.

As for days to first boll opening, the results indicated that early Pima, \{G.84 (G.74 × G.68)\} × Dendara, Giza 90, Suvin, Giza 83 and Sea Island did not differ significantly while Giza 88 and Pima S6 were later parental varieties. The results in Table (3) showed that 9 out of 25 crosses exhibited earlier mean performance with insignificant differences. While 7 out of 25 crosses exhibited later mean performance with insignificant differences.

(As for the earliness index, the data in (Table 3) showed that the cross Giza 88 $x$ Giza 45 was late than mid parent Giza $88 \times$ Giza 90 and five other hybrids expressed tendency toward lateness relative to better parent, The cross Giza $83 \times$ Giza 90 and [G.84 x (G.74xG.68)] $\times$ Giza 90 were earlier crosses for earliness index. These results indicated that the crosses G.83 $\times$ G.90, $\{$ G.84 $\times($ G.74 $\times$ G.68) $\} \times$ Early Pima could produce the earliest genotypes.

Results in Table (3) also indicate that the crosses G.83 x G.90, \{G.84 x (G.74 x G.68) $\} \times$ Early Pima and $\{$ G.84 $\times$ (G.74 $\times$ G.68) $\} \times$ Dendara exhibited earlier mean performance for first fruiting node and they did not differ significantly. While the crosses Giza $88 \times$ Sea Island, Giza $83 \times$ Giza 45, \{G.84 × (G.74 × G.68) $\} \times$ Giza 45, Pima $56 \times$ Sea Island, Giza $88 \times$ Giza 45 , Suvin $\times$ Sea Island and Suvin X Giza 45 were latest crosses and did not differ significantly. 

EARLINESS CHARACTERS FOR LINE X TESTER HYBRIDS OF COTTON

Table 3. Man performance heterosis and specific combining ability for F1, s hybrids

\begin{tabular}{|c|c|c|c|c|c|c|c|c|}
\hline \multirow{3}{*}{ Crosses } & \multicolumn{4}{|c|}{ First fruiting node } & \multicolumn{4}{|c|}{ Days to first flower } \\
\hline & \multirow{2}{*}{ Mean } & \multicolumn{2}{|c|}{ heterosis } & \multirow{2}{*}{ S.C.A } & \multirow{2}{*}{ Mean } & \multicolumn{2}{|c|}{ heterosis } & \multirow{2}{*}{ S.C.A } \\
\hline & & M.P & B.P & & & M.P & B.P & \\
\hline Pima S6x Early Pima & 5.58 & 0.72 & 2.76 & 0.006 & 75.73 & $-1.23^{*}$ & $6.36 * *$ & $1.723^{* *}$ \\
\hline Giza 88 x Early Pima & 5.68 & -1.73 & 4.6 & 0.216 & 72.75 & $-2.77 * *$ & $2.18^{* *}$ & -0.207 \\
\hline Giza 83 x Early Pima & 5.8 & 0.61 & $6.81^{*}$ & 57.53 & 67.45 & $-7.02 * *$ & $-5.27 * *$ & 57.53 \\
\hline $\mid \begin{array}{c}{[\mathrm{G} .84 \times(\mathrm{G} .74 \times G .68)] \times} \\
\text { Early Pima }\end{array}$ & 5.25 & $-9.72 * *$ & -3.31 & 61.53 & 69.35 & $-3.70 * *$ & $-2.60 * *$ & 61.53 \\
\hline Suvin $\times$ Early Pima & 5.45 & -3.2 & 0.37 & 0.146 & 65.45 & $-7.02^{* *}$ & $-5.94 * *$ & -0.107 \\
\hline Pima S6x Sea Island & 6.93 & $5.80^{*}$ & $22.65 * *$ & -0.059 & 81.28 & $-1.08 *$ & $-1.06^{*}$ & $2.428 * *$ \\
\hline Giza $88 \times$ Sea Island & 7.15 & $5.30^{*}$ & $16.64 * *$ & $0.276^{*}$ & 74.63 & $-7.08 * *$ & $-4.87^{* *}$ & $-3.177^{* *}$ \\
\hline Giza $83 \times$ Sea Island & 6.10 & $-9.96 * *$ & 0.00 & -0.134 & 77.93 & -0.13 & $5.48 * *$ & $2.173^{* *}$ \\
\hline$\left[\begin{array}{c}{[\mathrm{G} .84 \times(\mathrm{G} .74 \times G .68)] \times} \\
\text { Sea Island }\end{array}\right.$ & 6.43 & $-5.79 * *$ & 3.71 & -0.114 & 77.8 & 0.38 & $6.82^{* *}$ & $-0.672^{*}$ \\
\hline Suvin $\mathrm{x}$ Sea Island & 6.85 & 3.16 & $17.50^{* *}$ & 0.031 & 76.5 & 0.82 & $9.95^{* *}$ & $-0.752^{* *}$ \\
\hline Pima 56x Giza 45 & 6.5 & $-4.76^{*}$ & $15.04 * *$ & $0.396 * *$ & 78.3 & $-3.65 * *$ & $-2.59 * *$ & $-2.127^{* *}$ \\
\hline Giza $88 \times$ Giza 45 & 6.9 & -2.34 & $12.56 * *$ & $-0.444 * *$ & 77.98 & $-1.81^{* *}$ & -0.6 & $0.868^{*}$ \\
\hline Giza 83 x Giza 45 & 7.15 & 1.42 & $17.21^{* *}$ & $0.446 * *$ & 74 & $-4.06 * *$ & 0.16 & $-1.057^{* *}$ \\
\hline $\begin{array}{c}{[\mathrm{G} .84 \times(\mathrm{G} .74 \times \mathrm{G} .68)] \times} \\
\text { Giza } 45\end{array}$ & 7.08 & -0.28 & $14.19^{* *}$ & 0.116 & 77.78 & 0.38 & $6.80^{* *}$ & $2.373^{* *}$ \\
\hline Suvin x Giza 45 & 6.78 & -1.95 & $16.30^{* *}$ & $-0.514^{* *}$ & 70.63 & $-5.80^{* *}$ & $1.51^{*}$ & -0.057 \\
\hline pima $56 \times$ Dendra & 5.75 & 2.22 & 2.68 & $-0.224 *$ & 77.13 & $-1.17^{*}$ & $4.33^{* *}$ & $-0.877^{* *}$ \\
\hline Giza $88 \times$ Dendra & 5.65 & -3.67 & 0.89 & -0.189 & 72.45 & $-4.91^{* *}$ & $-2.00^{* *}$ & 0.093 \\
\hline Giza $83 \times$ Dendra & 5.55 & $-5.13^{*}$ & -0.89 & 0.301 & 74.75 & $1.14^{*}$ & $1.18 * *$ & $2.068 * *$ \\
\hline 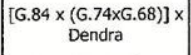 & 5.38 & $-8.81^{*}$ & -3.93 & -0.129 & 72.58 & $-1.09 *$ & -0.34 & -0.452 \\
\hline Suvin $\times$ Dendra & 5.58 & -2.36 & -0.36 & 0.241 & 67.83 & $-5.47 * *$ & $-2.52^{* *}$ & $-0.832 * *$ \\
\hline Pima S6x Giza 90 & 5.85 & 2.81 & 3.54 & -0.119 & 76.08 & $-1.41^{* *}$ & $5.40^{* *}$ & $-1.147^{* *}$ \\
\hline Giza $88 \times$ Giza 90 & 5.9 & -0.51 & 2.97 & 0.141 & 71.75 & $-4.73^{* *}$ & -0.6 & $2.423^{* *}$ \\
\hline Giza 83 x Giza 90 & 5.03 & $-14.96 * *$ & $-12.22 * *$ & -0.094 & 71.7 & $-1.82^{* *}$ & -0.67 & $-1.452^{* *}$ \\
\hline $\begin{array}{c}{[\mathrm{G} .84 \times(\mathrm{G} .74 \times \mathrm{G} .68)] \mathrm{x}} \\
\text { Giza } 90\end{array}$ & 5.85 & -1.93 & 2.09 & -0.024 & 71.58 & $-1.28^{*}$ & -0.83 & $-1.572^{* *}$ \\
\hline Suvin $\times$ Giza 90 & 5.8 & 0.35 & 1.22 & 0.096 & 70.53 & -0.49 & 1.37 & $1.748 * *$ \\
\hline LSD $(0.05)$ & 0.345 & 0.299 & 0.345 & 0.244 & 0.867 & 0.751 & 0.867 & 0.613 \\
\hline $\operatorname{LSD}(0.01)$ & 0.457 & 0.396 & 0.457 & 0.323 & 1.15 & 0.996 & 1.15 & 0.813 \\
\hline
\end{tabular}

*** Significant at $0.05 \%$ and $0.01 \%$, respectively 
Cont. Table 3.

\begin{tabular}{|c|c|c|c|c|c|c|c|c|}
\hline \multirow{3}{*}{ Crosses } & \multicolumn{4}{|c|}{ Days to first boll opening } & \multicolumn{4}{|c|}{ Earliness index } \\
\hline & \multirow{2}{*}{ Mean } & \multicolumn{2}{|c|}{ heterosis } & \multirow{2}{*}{ S.C.A } & \multirow{2}{*}{ Mean } & \multicolumn{2}{|c|}{ heterosis } & \multirow{2}{*}{ S.C.A } \\
\hline & & M.P & B.P & & & M.P & B.P & \\
\hline Pima S6x Early Pima & 133.95 & $3.11^{* *}$ & $5.60^{* *}$ & 1.538 & 57.53 & -2.23 & $-17.3^{*}$ & 1.45 \\
\hline Giza $88 \times$ Early Pima & 133.43 & $2.19 *$ & $5.19 * *$ & 0.408 & 61.53 & -12.9 & -14.24 & -3.714 \\
\hline Giza 83 x Early Pima & 127.38 & -0.96 & 0.42 & -1.237 & 55.35 & -14.43 & -20.39 & -3.661 \\
\hline$\underset{\text { Early Pima }}{[\mathrm{G} .84 \times(\mathrm{G} .74 \mathrm{G} .68)] \times} \times$ & 128.48 & 0.57 & 1.28 & -1.007 & 60.92 & -17.46 & $-21.9 *$ & 9.041 \\
\hline Suvin $\times$ Early Pima & 130.18 & 1.15 & $2.63^{*}$ & 0.298 & 66.72 & 6.7 & -4.04 & -3.116 \\
\hline Pima S6x Sea Island & 132.83 & 1.27 & $2.69 * *$ & 1.773 & 47.18 & -9.88 & -16.57 & 0.728 \\
\hline Giza $88 \times$ Sea Island & 129.95 & -1.41 & 0.46 & -1.707 & 50.36 & $-21.50^{*}$ & $-29.8^{* *}$ & -5.246 \\
\hline Giza $83 \times$ Sea Island & 129.6 & -0.2 & 0.19 & 0.198 & 59.72 & 2.62 & -0.2 & 2.797 \\
\hline$\underset{\text { Sea Island }}{[\mathrm{G} .84 \times(\mathrm{G} .74 \times \mathrm{G} .68)] \times} \times$ & 130.1 & 0.85 & 1.13 & -0.172 & 55.02 & -18.26 & $-29.5 * *$ & 0.817 \\
\hline Suvin $\times$ Sea Island & 130.95 & 0.77 & 1.24 & -0.092 & 63.82 & 13.88 & 12.86 & 0.904 \\
\hline Pima S6x Giza 45 & 134.1 & 0.84 & 0.84 & $-1.962^{*}$ & 57.82 & 9.82 & 1.17 & -4.514 \\
\hline Giza $88 \times$ Giza 45 & 132.68 & -0.71 & -0.23 & 0.258 & 63.72 & -1.13 & -11.19 & 5.04 \\
\hline Giza $83 \times$ Giza 45 & 132.03 & 0.27 & 1.27 & $1.863^{*}$ & 55.17 & -5.68 & -7.8 & -4.825 \\
\hline $\begin{array}{c}{[\mathrm{G} .84 \times(\mathrm{G} .74 \times G .68)] \times} \\
\text { Giza } 45\end{array}$ & 130.63 & -0.04 & 1.54 & -0.907 & 62.3 & -1.97 & $-20.2^{* *}$ & 1.565 \\
\hline Suvin $x$ Giza 45 & 130.2 & -1.19 & -0.27 & 0.748 & 68.95 & 22.38 & $20.7^{* *}$ & 2.735 \\
\hline pima $\mathrm{s} 6 \times$ Dendra & 130.95 & 0.06 & 1.71 & -1.152 & 69.49 & 19.65 & 2.18 & -1.488 \\
\hline Giza $88 \times$ Dendra & 131.03 & -0.37 & 1.77 & 0.468 & 65.98 & -5.58 & -8.04 & -2.202 \\
\hline Giza $83 \times$ Dendra & 127.98 & -1.22 & -0.6 & 0.173 & 65.79 & 2.92 & -3.26 & -0.239 \\
\hline$\underset{\text { [G.84 } \underset{\text { Dendra }}{(\mathrm{G} .74 \times G .68)}] \times \times}{\times}$ & 129.73 & 0.8 & 0.84 & 0.553 & 67.48 & -7.62 & -13.58 & 0.708 \\
\hline Suvin $\times$ Dendra & 131.45 & 1.39 & $2.10^{*}$ & -0.042 & 55.12 & -10.77 & -18.95 & 3.221 \\
\hline Pima 56x Giza 90 & 130.15 & -0.6 & 0.97 & -0.197 & 61.89 & -3.43 & $-22.7 * *$ & 3.825 \\
\hline Giza 88 x Giza 90 & 129 & $-1.97^{*}$ & 0.08 & 0.573 & 70.63 & -6.92 & -11.73 & 6.121 \\
\hline Giza 83 x Giza 90 & 127.53 & -1.63 & -1.06 & -0.997 & 71.53 & 2.29 & -10.61 & 5.929 \\
\hline $\begin{array}{c}{[\mathrm{G} .84 \times(\mathrm{G} .74 \times \mathrm{G} .68)] \times} \\
\text { Giza } 90\end{array}$ & 127.03 & $-1.36 *$ & -1.26 & 1.533 & 74.56 & -5.68 & -6.82 & $-12.131 *$ \\
\hline Suvin $\times$ Giza 90 & 126.9 & -2.18 & -1.55 & -0.912 & 68.08 & 0.45 & -14.92 & -3.744 \\
\hline LSD $(0.05)$ & 2.548 & 2.207 & 2.548 & 1.802 & 14.977 & 12.971 & 14.977 & 10.591 \\
\hline $\operatorname{LSD}(0.01)$ & 3.378 & 2.926 & 3.378 & 2.389 & 19.854 & 17.194 & 19.854 & 14.039 \\
\hline
\end{tabular}

*** Significant at $0.05 \%$ and $0.01 \%$, respectively 
These results indicated that early parent $x$ early parent produce early hyrids while early parents $x$ late parents produce late hybrids (Table 2 ).

Data in (Table 3) showed that seven out 25 crosses produced earlier first fruiting node than mid- parent these value ranged from -4.64 for Pima S6 x Giza 45 to $-14.96 \%$ for Giza $83 \times$ Giza.90. The cross Giza $83 \times$ Giza.90 exhibited earlier for first fruiting node than the better parent and exhibited higher heterosis than other crosses. Out 25 crosses nine expressed significantly positive heterotic effect relative to the better parent and two to mid parent. These heterotic effects were undesirable for position of first fruiting node. Specific combining ability was estimated for each individual cross in $F_{1}$ (Table 3 ). For position of first fruiting node, the cross of Giza 83 $\times$ Early Pima, Giza 88 × Giza 45 and Suvin × Giza 45 expressed high significant towards earliness. On the other hand, Giza $88 \times$ Sea Island, Pima S6 × Giza 45, Giza $83 \times$ Giza 45 and Giza $83 \times$ Dendara exhibited highly significant effects toward lateness.

The previous results indicated the crosses with high SCA effects did not always involve parent with high GCA effect, this finding is harmony with that was obtained by Patil et al., (1997).

Concerning days to first flower, 19 out 25 hybrids showed significant negative heterotic effect (earliness) relative to mid parent. The range of heterosis was between $-1.17 \%$ for Pima S6 $\times$ Dendara to $-7.08 \%$ for Giza $88 \times$ sea Island (Table 3 ) One hybrid (G.88 x dendra) expressed significantly positive heterotic effect. The data of days to first flower also showed that eight hybrids which exhibited tendency for earliness (negative heterotic effect) relative to the better parent. The values of these heterosis ranged from $-1.06 \%$ for Pima S6 $x$ sea island to $-5.27 \%$ for Giza $83 \times$ Early Pima. While ten hybrids exhibited tendency for lateness relative to better parent. The hybrids Giza 83 × Early Pima, [G.84 x (G.74 x G.68)] × Early Pima, Suvin × Early Pima, Suvin $\times$ Dendara, Giza $88 \times$ Sea Island and Suvin $\times$ Dendara were earlier than the other hybrid for days to first flower as their heterosis relative to mid and better parent were $-7.02 \%$ and $-5.27 \%,-3.70$ and $2.60 \%,-7.02$ and $-5.49 \%,-7.08 \%$ and $4.89 \%,-5.47 \%$, and $-2.52 \%$ respectively.

Concerning the days to first flower, the data in (Table 3) indicate that 11 out of 25 top crosses exhibited SCA effect toward early flowering. The cross Giza $83 \times$ Early Pima had SCA effect on position of first fruiting node and days to first flower for earliness direction and its female (Giza 83) was good combiner for earliness. Regarding days to first opening boll, the data in (Table 3) showed that two out 25 
hybrids exhibited significant negative heterotic effect relative to mid parent where the value of heterosis $-1.97 \%$ to -2.18 for Giza 88 x Giza 90 and Suvin x Giza 90 respectively and two crosses exhibited to lateness.

Five crosses exhibited lateness relative better parents (Table 3). Data in (Table 3) indicate that the cross Pima $S_{6} \times$ Giza 45 . expressed earliness for most of the characters and its male Giza 45 was good combiner. These results indicate that this cross might be of interest in breeding programs to develop early varieties. Concerning the early index the results in Table (3) indicated that only Suvin x Giza 45 exhibited highly significant heterotic effect relative better parent and mid parent. Regarding the earliness index, Table (3) showed the all crosses did not exhibit desirable SCA effects. These finding disagreed with those were obtained by Shunmugarallin and Das-Idv (1995).

\section{Heritability}

Estimates of broad sense heritability were high except for earliness index, which was low. These results were partially in agreement with those were obtained by Soliman (1999). Results in Table (4) showed that the narrow sense heritability were moderate for position of first fruiting nod and day to first flower and low for days to first boll opening and earliness index, when the values were $32.88 \%, 31.57 \%$ 16.91and $8.38 \%$, respectively. El-Adl et al. (2000) reported same trend as they reported $56.425,40.02 \%$ and $1.7 \%$ for days to first flower, days to first boll opening and earliness index, respectively, El-Feki (1986) found that low narrow sense heritability for position of first fruiting node, medium values for day to first flower and high values for day to first boll opening and earliness index.

Table 4. Estimates of broad and narrow sense heritability

\begin{tabular}{|c|c|c|c|c|}
\hline Sources & First fruiting node & $\begin{array}{c}\text { Days to first } \\
\text { flower }\end{array}$ & $\begin{array}{c}\text { Days to first boll } \\
\text { opening }\end{array}$ & Earliness index \\
\hline$h^{2}{ }_{b}$ & 89.933 & 98.267 & 58.835 & 17.66 \\
\hline$h^{2}{ }_{n}$ & 32.886 & 31.570 & 16.918 & 8.38 \\
\hline
\end{tabular}

$h^{2} b=$ broad sense heritability, $\quad h_{n}^{2}=$ narrow sense heritability

\section{Similarity and classification distance}

The measure of similarity and classification distances for earliness characters are shown in Tables (5 and 6) and dendrograms (1,2,3 and 4).

\section{D.1. Parents}

The data in (Table 5) showed that the parents diversity is demonstrated by the range in average taxonomic distance from 2.11 to 9.33 and similarity level from 93.72 to 72.28 . The dendrogram in Figs ( 1 and 2 ) indicated that the parents were 
agglomerated into two clusters group at levels of similarity and distance 72.28 and 9.326 respectively. All parents except parent number 1 (Pima $\mathrm{S}_{6}$ ) represent the first Cluster group, while the parent number 1 (pima $\mathrm{S}_{6}$ ) represent the second group. This result indicating that dissimilarity between the parent number 1 (Pima $\mathrm{S}_{6}$ ) and other parent was highest.

The dendrogram ( 1 and 2 ) showed that the first cluster group was divided into two-cluster group at distance and similarity levels 8.92 and 73.48 respectively. The parent $\{[G .84 \times$ (G.74 x G.68)], Giza 90\} represent the first sub group, While (Dendra, Early Pima), Giza 88. (Giza 45, Sea Island) and (Suvin, Giza 83) represent the second subgroup. Which was divided into sub subgroup (Dendra, Early Pima, Giza 88) and (Giza 45, Sea Island Sea Island), (Suvin, Giza 83). The results of dendrogram (5 and 6) indicated that the parents \{Giza 90 and [G.84 x (G.74 x G.68)]\}, (Dendra, Early Pima), (Giza 45, Sea Island) and (Suvin, Giza 83) were closely related to each other for earliness characters.

Table 5. Euclidean method for ten cultivars including two groups For genotypes, distance and similarity for earliness characters

\begin{tabular}{|c|c|c|c|c|c|}
\hline \multirow{2}{*}{ Node } & \multicolumn{2}{|c|}{ Cluster joined } & \multirow{2}{*}{ Distance } & Similarity & \multirow{2}{*}{ N .o. obs } \\
\cline { 2 - 3 } & Group 1 & Group 2 & & 93.72 & 2 \\
\hline 1 & 4 & 10 & 2.114 & 89.12 & 2 \\
\hline 2 & 6 & 9 & 3.661 & 87.72 & 2 \\
\hline 3 & 7 & 8 & 4.133 & 81.88 & 2 \\
\hline 4 & 3 & 5 & 6.097 & 77.00 & 4 \\
\hline 5 & Node 4 & Node 3 & 7.737 & 75.98 & 3 \\
\hline 6 & 2 & Node 2 & 8.080 & 75.19 & 7 \\
\hline 7 & Node 6 & Node 5 & 8.346 & 73.48 & 9 \\
\hline 8 & Node 7 & Node 1 & 8.921 & 72.28 & 10 \\
\hline 9 & 1 & Node 9 & 9.326 & & 2 \\
\hline
\end{tabular}

$\begin{array}{cccc}1 & \text { Pima S }_{6} & 6 & \text { Early Pima } \\ 2 & \text { Giza } 88 & 7 & \text { Sea Island } \\ 3 & \text { Giza } 83 & 8 & \text { Giza45 } \\ 4 & \text { G.84 } \times \text { (G.74xG.68) } & 9 & \text { Dendra } \\ 5 & \text { Suvin } & 10 & \text { Giza90 }\end{array}$


Table 6. Euclidean method for 25 genotypes including two group for genotypes, distance and similarity for earliness characters.

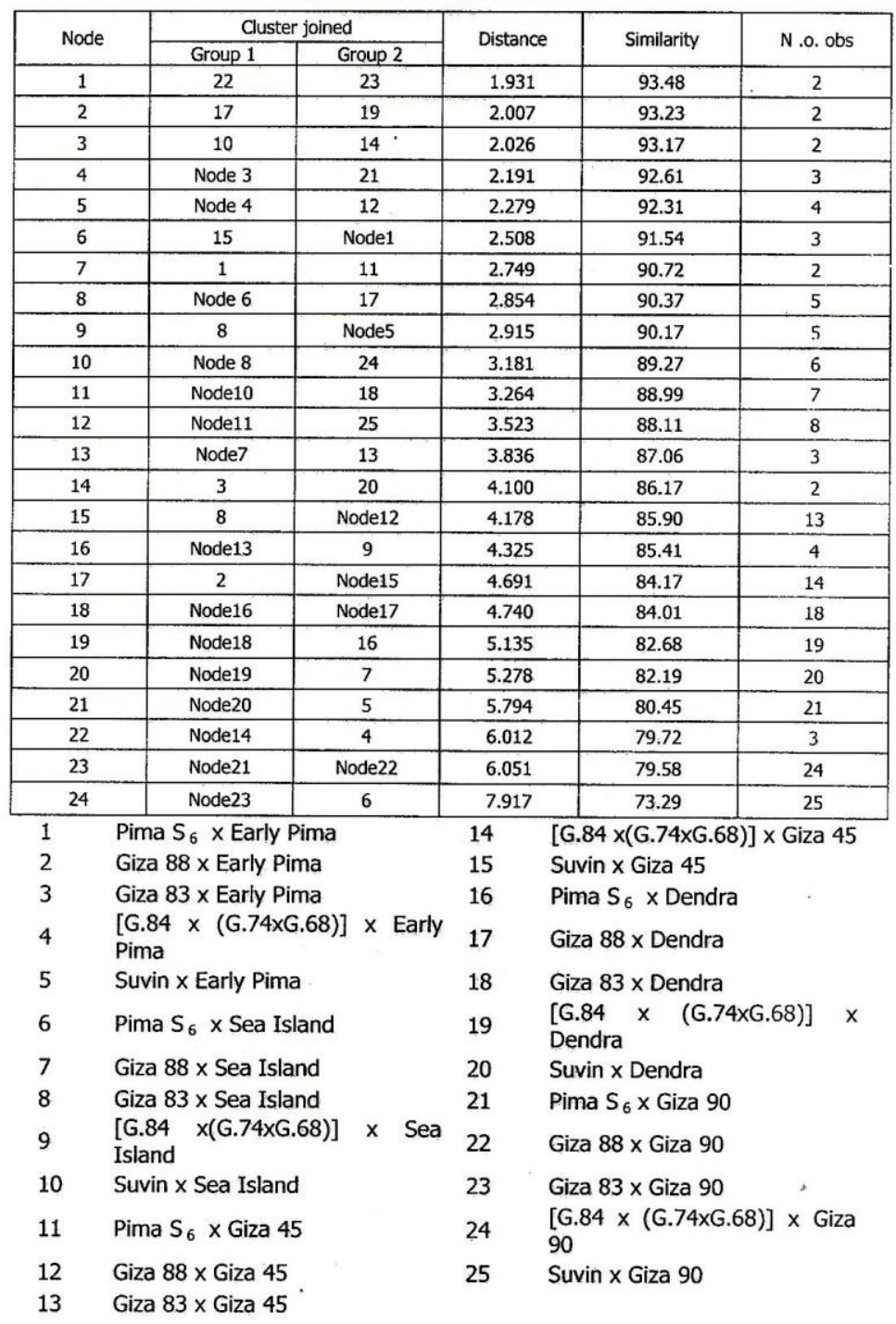




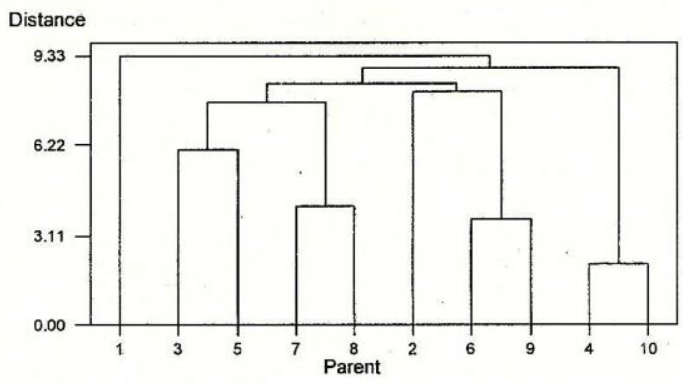

Fig1. Dendrogram of taxonomic distance for ten parents Constructed from earliness characters

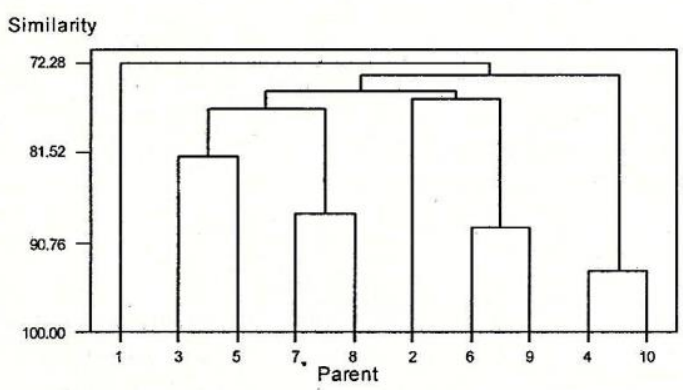

Fig 2. Dendrogram of coefficient similarity for ten parents constructed from earliness characters

$\begin{array}{cccc}1 & \text { Pima s6 } & 6 & \text { Early Pima } \\ 2 & \text { Giza 88 } & 7 & \text { Sea Island } \\ 3 & \text { Giza 83 } & 8 & \text { Giza45 } \\ 4 & \text { G.84 } \times \text { (G.74xG.68) } & 9 & \text { Dendra } \\ 5 & \text { Suvin } & 10 & \text { Giza90 }\end{array}$

The dendrogram (1 and 2) showed that the first cluster group was divided into two-cluster group at distance and similarity levels 8.92 and 73.48 respectively. The parent $\{[G .84 \times(G .74 \times$ G.68) ], Giza 90\} represent the first sub group, While (Dendra, Early Pima), Giza 88. (Giza 45, Sea Island) and (suvin, Giza 83) represent the second subgroup. Which was divided into sub subgroup (Dendra, Early Pima, Giza 88) and 
(Giza 45, Sea Island Sea Island), (suvin, Giza 83). The results of dendrogram (5 and 6) indicated that the parents \{Giza 90 and [G.84 x (G.74 x G.68)]\}, (Dendra, Early Pima), (Giza 45, Sea Island) and (suvin, Giza 83) were closely related to each other for earliness characters.

\section{E. 2. The Crosses}

Table (6) and figures ( 3 and 4 ) showed that the cross Pima $S_{6} \times$ Sea Island does not join with other crosses until distance and similarity levels were 7.92 and 73.29 , respectively. This indicated the presence is high level of dissimilarity between the cross (Pima S6 $\times$ Sea Island) and other crosses. From dendrogram it appears that (Giza 88 x Giza 90, Giza 83 x Giza 90), ([G.84 × (G.74 x G.68)] x Dendra, Giza 88 × Dendra), (Suvin $\times$ Sea Island, [G.84 x(G.74 x G.68)] x Giza 45), ( node 3, Pima S6 x Giza 90) ( node 4, Giza 88 x Giza 45) , (node 15, Suvin x Giza 45), (node 8, Giza 83 x Sea Island), (node 6, Giza 83 x Dendra) and ( node 6, Suvin x Giza 90) are closely related to each other. These cluster groups were agglomerated as two groups. The two groups joined only and distance and similarity levels are 4.18 and 85.90 .

The cluster groups (nod 14, [G.84 x (G.74xG.68)] x Early Pima) and (nod 21, nod 22) did not join until the distance and similarity levels reached 6.05 and 79.58 respectively. This result indicates that the cross ([G.84 x (G.74xG.68)] x Early Pima) does was nor related to other crosses except the cross (PimaS6 $\times$ Sea Island) until the distance and similarity levels 6.05 and 79.58 respectively. The cross Giza $88 \times$ Early Pima was not related with 18 out 25 crosses until the distance and similarity level 4.74 and 84.01 respectively.

The distance and similarity between the cross Pima S6 $x$ Dendra and the other 19 crosses were 5.13 and 82.68 (Fig 3 and 4). The cross (Suvin x Early Pima) was not related with 21 out 25 crosses until the distance and similarity level 5.77 and $80.45 \%$, respectively. From the previous results, it be concluded that crosses Pima S6 $\times$ Dendra, Giza $88 \times$ Sea Island, Suvin x Early Pima, [G.84 x (G.74 x G.68)] x Early Pima and Pima S6 x Sea Island showed longer distance between these crosses. 


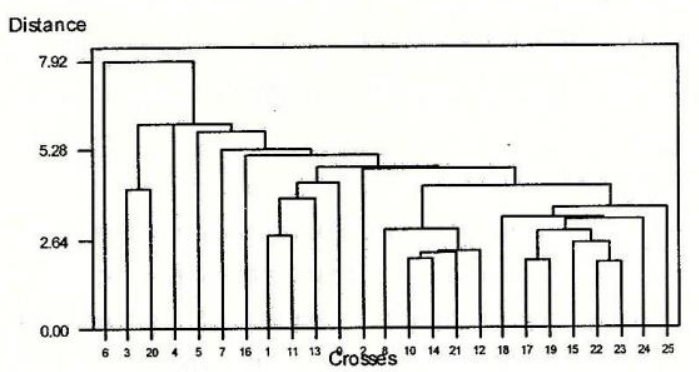

Fig 3. Dendrogram of taxonomic distance for crosses Constructed from earliness characters

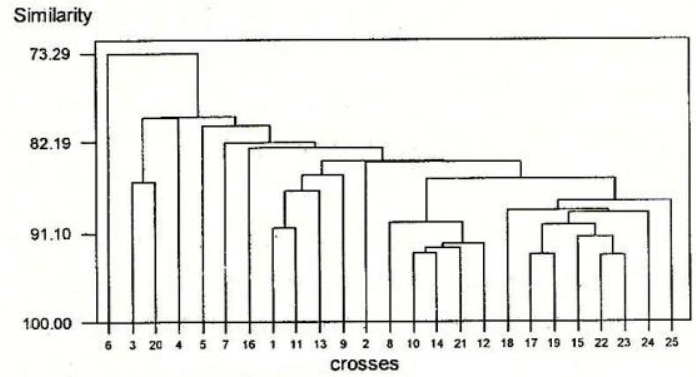

Fig 4. Dendrogram of coefficient similarity for crosses constructed from earliness characters

\begin{tabular}{|c|c|c|}
\hline Pima $S_{6} \times$ Early Pima & 14 & [G.84 x(G.74xG.68)] x Giza 45 \\
\hline Giza 88 x Early Pima & 15 & Suvin $\times$ Giza 45 \\
\hline Giza $83 \times$ Early Pima & 16 & Pima $\mathrm{S}_{6} \times$ Dendra \\
\hline [G.84 x (G.74xG.68)] x Early Pima & 17 & Giza 88 x Dendra \\
\hline Suvin $x$ Early Pima & 18 & Giza 83 x Dendra \\
\hline Pima $\mathrm{S}_{6} \times$ Sea Island & 19 & {$[\mathrm{G} .84 \times(\mathrm{G} .74 \times \mathrm{G} .68)] \times$ Dendra } \\
\hline Giza 88 x Sea Island & 20 & Suvin $\times$ Dendra \\
\hline Giza 83 x Sea Island & 21 & Pima $\mathrm{S}_{6} \times$ Giza 90 \\
\hline$[\mathrm{G} .84 \times(\mathrm{G} .74 \times \mathrm{G} .68)] \times$ Sea Island & 22 & Giza 88 x Giza 90 \\
\hline Suvin $\times$ Sea Island & 23 & Giza 83 x Giza 90 \\
\hline Pima $S_{6} \times$ Giza 45 & 24 & [G.84 x (G.74xG.68)] x Giza 90 \\
\hline Giza 88 × Giza 45 & 25 & Suvin x Giza 90 \\
\hline
\end{tabular}


The dendrogram show that the crosses (Giza $83 \times$ Giza 90, Giza $83 \times$ Dendra), $\{[G .84 \times(G .74 \times$ G.68) $] \times$ Giza 90\}, ( [G.84 × (G.74 x G.68)] × Dendra) , (Suvin $\times$ Giza 45, Pima $\mathrm{S}_{6} \times$ Giza 45, Giza $88 \times$ Sea Island), (Suvin $\times$ Early Pima, Giza $88 \times$ Giza 90), (Giza $88 \times$ Sea Island, Giza $88 \times$ Early Pima), (Suvin $\times$ Dendra, Suvin $\times$ Sea Island, Giza 83 × Early Pima), [G.84 × (G.74 x G.68)] x Giza 45, Giza $88 \times$ Giza 45) were closely related with each other and other crosses. The hybrid (Pima S6 $\times$ Sea island) exhibited high level are dissimilarity due to their parent were high distant this results indicated that diversity of the crosses pending

Our result of earliness characters indicated the cross Giza $88 \times$ Giza 90 was the earliest, while the cross Pima S6 $\times$ Sea Island was the lateness. These results were harmony with those obtained by multivariate analysis in Table (6). which showed that the distance between two crosses was very wide and the similarity was low level. Table (5) showed that when the distance between parents of any two crosses were high, the similarity was low indicating that genetic diversity among parents was reflected in their progenies. Similar results were obtained by Soundue and Boparai (1997) On the other hand Patile et al., (1999) suggested that there was no correspondence between the divergence of parent as measured by generalized distance between them and extent of superiority of F1's

\section{REFERENCES}

1. Abou El-Yazied, M. A. 1999. Estimation of some genetic parameters of economical characters in cotton. M.Sc. Thesis, Fac. of Agric. Mansoura, Univ., Egypt.

2. Awad, A. A. M. 2001. Genetic studies for some quantitative characters in an intraspecific cotton cross (Gossypium barbadense L.). J. Agric. Res. Tanta Univ., 27(4): $698-708$.

3. El-Adl, A. M., Z. M. El-Diasty, A. A. Awad and A. M. R. Abd El-Bary. 2000a. Inheritance of quantitative traits of Egyptian cotton (G. barbadense L.). b- Earliness and fiber traits. J. Agric. Sci. Mansoura Univ., 25(10): 6153-6165.

4. El-Feki 1986. heterosis and combining ability for yield and components, fiber and yarn properties in intra-and interspecific crosses of cotton. Ph.D. Thesis, Ain Shams univ, Egypt

5. El- Feki et al. 1995. heterosis and combining ability in top crosses of cotton. 1995 Proceedings Beltwide cotton Conferences, San Antonio, TX, USA, 4-7January,1995: volume1, 588-590.

6. El-Tabbakh, S. S. and F. S. El-Nakhlawy. 1995. Estimation of general and specific combining ability for seed cotton yield and its components through a $(5 \times 5)$ diallel cross analysis. Minofiya J. Agric. Res., Vol. 20(2): 493-505. 
7. Gomaa, M. A. M. and A. M. A. Shaheen. 1995b. Earliness studies in inter-specific cotton crosses. Annals, Agric. Sci., Ain--Shams Univ., Cairo, 40(2): 629-637.

8. Hassoub, E. K. 1991. Breeding cotton for some quantitative characters. Ph.D. Thesis Fac. of Agric. Univ. Minufiya, Egypt.

9. El-Lawendey, M. M. A. 1999. Studies on cotton breeding. M.Sc. Thesis, Fac. of Agric., Fac. of Agric., Kafr El-Sheikh, Tanta Univ., Egypt.

10. Patel, U. G., J. C. Patel, P.G. Patel, K. V. Vadodaria and C. Sutaria. 1997. Combining ability analysis for seed cotton yield and mean Fiber length in upland cotton (G.hirsutum L. ) Indian J. of Gen. And plant breeding. 57(3): 315318

11. Shunmugavalli, N., and L. D. V. Das. 1995. Line $x$ tester analysis of combining ability in cotton. Madras Agric. J. 286 (8): $449-452$.

12. Rajput, J. P., L. D. Meshram, H.V. Kalpande, S. R. Golhar and S. Bhard. 1997. Heterosis studies in Asiatic cotton (Gossypium spp.)

13. Soliman, Y. A. M. 1999. Studies on some economic characters in some cotton crosses., M.Sc. Thesis, Fac. of Agric. Kafr El-Sheikh, Tanta Univ., Egypt.

14. Singh, R. K. and B. D. Chaudhary. 1979. iometrical Methods in Quantitative Genetic Analysis. 2nd ed., Kalyani, Publishers, Daryagani, New Delhi. 
تحديد الأباء والهجن المتميزة في صفات التبكير في الهجن القمية للقطن

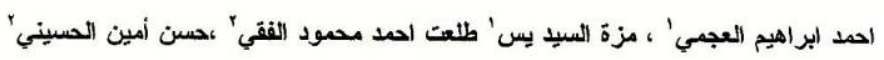

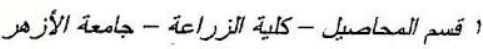

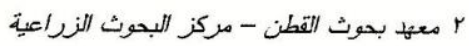

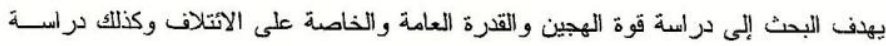

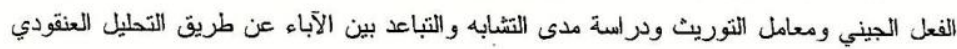

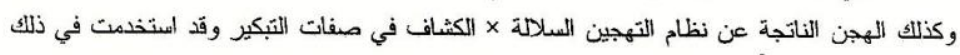

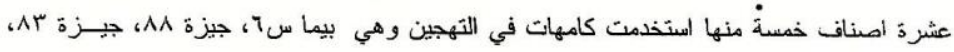

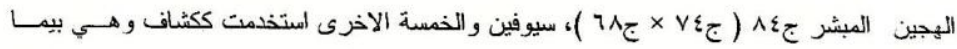

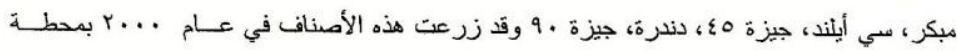

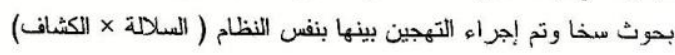
ويمكن تلخيص النتائج المتحصل عليها فيما يلي لئي

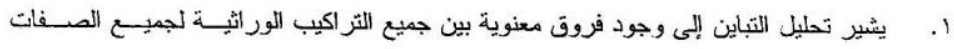
المدروسة فئة

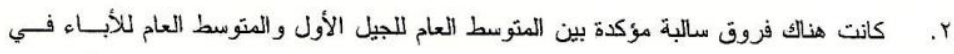

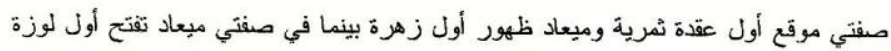

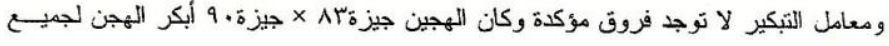
صفات التبكير

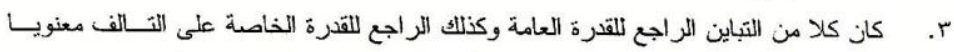

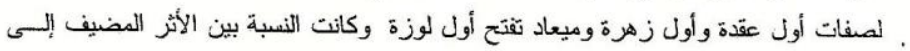

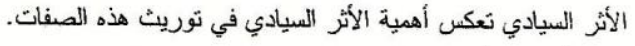

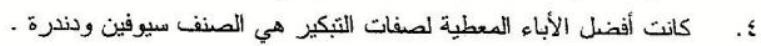

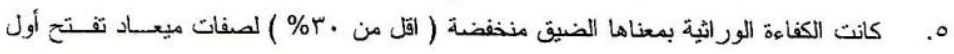

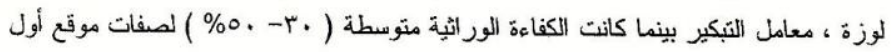

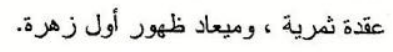

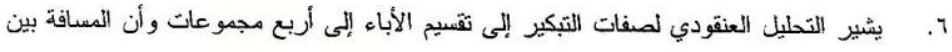

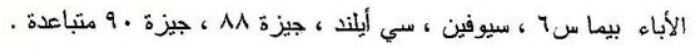

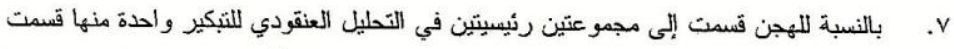

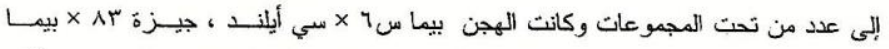

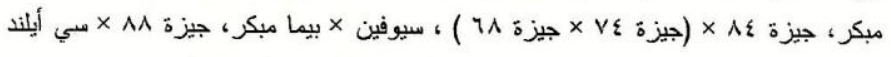

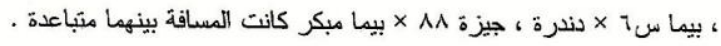

